\title{
Chemical weapons ban edges to realization
}

London. Prospects for a worldwide ban on the production, possession and use of chemical weapons edged a step closer last month with the long-awaited publication by the British government of draft legislation to ratify the Chemical Weapons Convention (CWC).

Britain has been one of the key participants in negotiating the convention. Both the United States and Russia, which between them possess most of the world's chemical warfare agents and are said to have used offensive chemical weapons during the past decade, have yet to announce ratification plans (both have signed).

A consultation paper for a bill to ratify the convention, which was signed in Paris in January 1993, was issued by Britain's Department of Trade and Industry on 19 July. The deadline for comments is 29 September and the bill will be debated in the House of Commons when parliament reconvenes in October.

"The Chemical Weapons Con-

vention will help rid the world of Endangered species? Progress in outlawing chemical these weapons of mass destruc- weapons (seen here in Iraq) seems set to accelerate. tion", Anthony Nelson, the trade

minister, said in a written statement. "The UK is committed to the convention, and wants to ratify it as soon as possible."

The convention makes it illegal for its 159 signatory states to possess, use or sell chemical weapons. All existing weapons must be destroyed within the first decade of the treaty coming into force. This will take place 180 days after the first 65 countries announce completion of relevant primary legislation in their national parliaments.

The British government's announcement is being widely interpreted as a sign that progress to ratify the CWC should now begin to pick up. Thirty-two countries including France, Germany, Norway, Spain, Sweden, Switzerland and Australia - have already formally announced completion of legislation to ratify the convention. A further 16 states, including Japan, Canada, South Africa, Algeria and the Netherlands, are understood to be close to ratification.

Competition for the remaining positions is likely to be tough, as only the first 65 nations to ratify will be allowed to influence the body that will be set up to oversee the treaty, the Organization for the Prohibition of Chemical Weapons (OPCW). This agency will employ 470 people at its headquarters in the Dutch capital, The Hague. It will have an annual budget of US\$100 million.

Britain is believed to be keen to join this first tier of countries to ratify the CWC. A British diplomat, Ian Kenyon, already heads the OPCW's international secretariat, based in The Hague, which is a nucleus for the projected technical secretariat.

Early ratification for Britain, which formally abandoned the offensive use of chemical and biological weapons in the late 1950s, would also secure the long-term future of Britain's historic Chemical and Biological Defence Establishment at Porton Down.

When the United States and Russia announce plans to ratify "the rate at which other countries do so will increase", predicts Julian Perry Robinson, a chemical weapons

IMAGE
UNAVAILABLE
FOR COPYRIGHT
REASONS

expert at the Science Policy Research Unit at the University of Sussex.

Countries that have yet even to sign the CWC include Egypt, Iraq, North Korea, Syria, Libya, Taiwan, Somalia and Sudan, as well as those of the former Yugoslavia. All are believed to have used chemical weapons. Israel, another reported user, has signed the CWC, but has yet to ratify.

The British announcement has been welcomed by the country's chemical industry, which will be affected most by the CWC's widespread verification procedures.

The convention is the most rigorous of any comparable international agreements. In addition to banning chemical weapons, it will keep a tight rein on the use of chemicals that can potentially be used in warfare but

\section{Moon landing film 'gave lift' to space station}

Washington. The US House of Representatives has given its overwhelming support to a \$2.1-billion budget for work on the international space station in the next financial year, which begins on 1 October, assuring the project's continuation.

In debating an appropriations bill covering the National Aeronautics and Space Administration (NASA) last week, the House rejected by 299 votes to 126 an amendment from David Obey (Democrat, Wisconsin) that would have diverted the funding into social programmes.

It also rejected another amendment from Tim Roemer (Democrat, Indiana), to use the savings for reducing the general budget also have legitimate industrial uses.

Implementation of the CWC will be the responsibility of a regulatory authority in each country. Organizations dealing in dualuse chemicals will be obliged to declare this information to their respective authorities, and to accept site inspections on demand.

Industry concern had also been heightened because of adverse publicity generated by the association with chemical weapons. "We are disappointed the United Kingdom did not ratify earlier," says David Culpin, director of external affairs at the Londonbased Chemical Industries Association. It was involved in the framing of the CWC. Industry comments have been taken into account in drafting the government's bill.

But enthusiasm for the draft bill is not universally shared. Some scientists object to the decision not to create an independent agency to oversee the CWC in the United Kingdom. Verification will instead be the responsibility of a unit within the Department of Trade and Industry (DTI).

Doubts about the implications of this decision have been highlighted by the DTI's controversial role in exports to Iraq before the 1991 Gulf War. Critics also point out that the unit will apparently function with little recourse to independent advice, and without a discernible line of accountability.

"Ideally, this unit or organization should have input from independent scientific bodies", says Alastair Hay, senior lecturer in chemical pathology at the University of Leeds. "It is now vital this unit at least be scrutinized by the DTI select committee, so that outside experts and concerned groups can ask relevant and pertinent questions."

The opposition Labour Party, committed to enabling the "speedy passage" of the bill through parliament, stresses its offer is not a blank cheque. "This issue is too important to be left to internal committees", says the party's trade and industry spokesman, Lewis Moonie. "There must be clear accountability to parliament."

Ehsan Masood

deficit, by $287: 132$. The wide margins reflected strong support for the project from both the administration and the House Republican leadership.

After the vote, Roemer blamed his defeat partly on the success of the movie Apollo 13. "I feel like I'm competing against Tom Hanks," he said. But George Brown (California, Democrat), a long-standing supporter of the station who surprised many by defecting to support the Obey amendment, predicted that budget cuts at NASA would eventually make the project unsustainable. "We're cutting the dog's tail off an inch at a time," he said. "You can only go on doing that for so long." C. M. 